\title{
SOSYAL MEDYA KAYNAKLI OLAYLARIN GELENEKSEL HABER MECRALARINDA KULLANIMI
}

\author{
Use of Social Media Related Events in Traditional \\ News Media
}

\section{Kevser Seda Durmuş ${ }^{1}$}

\begin{abstract}
ÖZ: Yeni teknolojilerin gelişimi ve değişimi ile birlikte günlük hayatın vazgeçilmezi haline gelen sosyal medyanın gücü ve etkisi yadsınamaz bir gerçektir. Sosyal medyanın etkilediği alanlardan birisi de haberciliktir. Sosyal medya haberlerinin geleneksel medyada kimi zaman ülke gündemini kimi zaman dünya gündemini etkilediği görülmektedir. Bu noktadan hareketle sosyal medya kaynaklı haberlerin geleneksel haber mecralarında ne sıklıkla yer aldığının araştırılması amaçlanmıştır. Çalışmanın amacına ulaşmak için geleneksel haber mecralarında sosyal medya kaynaklı olayların kullanımı, nicel araştırma tekniği olan içerik analizi yöntemiyle incelenmiştir.
\end{abstract}

Anahtar Kelimeler: Sosyal Medya, Geleneksel Habercilik, İnternet Haberciliği, Ticari Açıklık, Ekonomik Büyüme.

\begin{abstract}
The power and influence of the social media, which has become indispensable to daily life with the development and change of new technologies, is an indisputable reality. One of the areas affected by social media is news. It is seen that social media news sometimes affects the country agenda and sometimes world agenda in the traditional media. From this point of view, it is aimed to investigate how frequently the social media news takes place in the traditional news circles. The purpose of the study was to examine the use of social media events in traditional news media by means of content analysis, a quantitative research technique.
\end{abstract}

Key Word: Sosial Media, Traditional Journalism, Internet Journalism.

1 Yüksek Lisans Öğrencisi, Selçuk Üniversitesi, Radyo Televizyon ve Sinema Ana Bilim Dal1, e-posta: ksedadurmus@gmail.com, 0RCID: 0000-0002-3837-6770.

Hakemli Araștırma Makalesi | Peer-reviewed Research Article

\begin{tabular}{|c|c|c|}
\hline Başvuru|Submission & Kabul|Accept & Yayın | Publish \\
\hline 08.06 .2020 & 17.06 .2020 & 29.06 .2020 \\
\hline
\end{tabular}




\section{GİRIŞ}

Günümüzde teknolojik gelişmelerde yaşanan dönüşümlerle birlikte gündeme gelen sosyal medya, popülerliğini her geçen gün daha fazla artırmaktadır. Bununla birlikte iletişim uygulamalarına doğrudan kaynaklık etmesi bakımından da oldukça önemlidir.

Sosyal medyada yayımlanan bilgilerin iletişimde zaman ve mekan farkını ortadan kaldırmasıyla birlikte bilgilerin hızlı bir şekilde ulaşılabilirliğini artırmaktadır. Yaygınlaşan bu yeni paylaşım sitelerindeki bilgiler, doğrudan gazete, televizyon veya internet haberciliğinde kaynak olarak kullanılmaktadır.

$\mathrm{Bu}$ çalışmada, televizyonların ana haber bültenlerinde, gazetelerde ve internet haber sitelerinde kullanılan, sosyal medyada öne ç1kan olaylar içerik analizi yöntemiyle incelenmiştir. Bu mecralarda yer verilen sosyal medya kaynaklı haberler 02. 04- 16.04. 2018 tarihleri arasında analiz edilmisstir. Yapılan analiz sonucunda sosyal medya kaynaklı olayların internet haberciliğinde yoğun olarak kullanıldığı görülmüştür.

\section{Haber Nedir?}

Bir hikâye olarak haber ve haber hikâyelerinin yapılarına bakmadan önce "haber nedir?" sorusuna yanıt aramak daha doğru olacaktır.

Türk Dil Kurumu, haber için üç tanım yapmıştır. TDK'ya göre haber: 1. Bir olay, bir olgu üzerine edinilen bilgi, salık, 2 . İletişim veya yayın organlarıyla verilen bilgi, 3 . Bilgi. ${ }^{2}$ Yapılan üç tanımda da haberin bilgi verme, enformasyon olduğu üzerinde durulur.

Günümüzde gelişen kitle iletişim araçları ise haberin yayılması ve kitlelere ulaşması bakımından önemli bir rol üstlenmektedir. İnsanların gerek yakın gerekse uzak çevrelerinde olup bitenler hakkında bilgi almalarını, günümüzde özellikle bu amaçla geliştirilmiş ve uzmanlaşmış bazı araçlar sağlamaktadır. Bu araçlara genel bir terim kullanarak kitle haberleşme araçları adını veriyoruz. Endüstri teknolojisinin gücünü simgeleyen kitle haberleşme araçları, kitleleri haberleşme ağıyla birbirine bağlamaktadırlar (Tokgöz, 1981: 3).

Gazeteler, dergiler, radyolar, televizyon kanalları ve internetten her gün milyonlarca insan yararlanmaktadır. Bu araçlar ise günlük yaşantımızın adeta bir parçası haline dönüssmüştür. Buralardan sağlanan bilgiye bilinçli ya da bilinçsiz bir şekilde maruz kalırız. Bilgi saylayan bu iletişim araçlarını kimi kendi çıkarları amacıyla kullanırken kimi ise bilgi almak ve çevresinden haberdar olabilmek için kullanır. 
Günümüzde gelişen teknolojiyle birlikte bilgi telefonlarımızla ceplerimize kadar ulaşmış durumdadır.

\section{Geleneksel Medya}

Geleneksel medya; Geleneksel, yani yazılı ve görsel basın (Gazeteler, Dergiler, Televizyon), olayların bu kanallar vasıtasıyla insanlara haber olarak duyurulduğu ve bu yolla iletişim kurulan bir ortamdır. Geleneksel medyanın yayın organları, çok büyük kitleleri kapsamaktadır. Tek taraflı bir medya olduğu için medya içeriğini bizlere sunar ve karşılığında biz bunları tüketiriz. İçerik üzerinde değişiklik veya yorum yapamaz ve içeriği yayınlayamayız. Tek taraflı bir medya olmasının yanı sıra maliyeti de yüksektir. Bu özelliklere rağmen sonuç her zaman daha net olur (Avluoğlu, 2017 ET: 10.06.2018).

Geleneksel medyanın yeni medyaya oranla içeriğinin yayımı yavaş; kapsama alanı ise daha dardır. Örnek verecek olursak; bir olayın gazetede yer alıp okuyucuya ulaşması bir gün sürerken, yeni medyada aynı olay aynı gün ve aynı saatte ulaşabilmektedir. Yerel medya ile izleyici ya da okuyucu arasındaki feedback olmasına rağmen yeni medyanın yanında geri dönüşümü daha zayıf kalmaktadır. Geleneksel medyada kitle, bir noktada seçeceği haber yayın organını kendi belirler. Geleneksel medyada yazilan her makale, yapilan her haber, bir denetim sürecinden geçer, onay verilmeyen yazılar yayımlanmaz. Geleneksel medyada yapilacak olan herhangi bir hatanın düzeltilmesi en az bir gün zaman almaktadır. Geleneksel medyanın zaman ve yer k1sitlılı̆g 1 söz konusudur. Şöyle ki; televizyon haberlerinde, haberin önem sırasının yanı sıra haber süresinin uzunluğu da dardır. Örneğin,10 dakikalık bir haber olayının ana haberlerde tamaminın izletilmesi beklenemez. Gazetelerde ise satır ve sütun kaygısı vardır.

Geleneksel medyayı eleştirel teoriler ve liberal yaklaşımlar olarak iki ana başlıkta toplayabiliriz. Yaylagül, eleştirel çalışmaların kısmen Marksizm'den esinlendiğini belirtir. Marx, temel/üstyapı formülasyonunda kültür ve ideolojiyi üstyapının unsurları olarak görmüştür. Yine de eleştirel akımlar, köken olarak Marksizm 'den etkilenmelerine rağmen kendi içlerinde farklılaşırlar (Yaylagül, 2014: 91-92). Dolay1siyla eleştirel teoriler, medya tarafından verilen bir mesajın er ya da geç bireyler tarafından benimseneceği ve bireylerin rızasının kazanılacağını savunmaktadırlar (Erdoğan ve Alemdar, 2005: 59-67).

Başta Kullanımlar ve Doyumlar Yaklaşımı olmak üzere medyaya yönelik liberal yaklaşımlar ise, eleştirel teorilerin aksine medyanın izleyicileri yönlendirmek gibi bir gücünün olmadığını, aksine medyanın kontrolünün bireylerde olduğunu savunmaktadır. 
Medyanın gücünün sınırlı olduğunu savunan liberal yaklaşımlar "İnsanlar medya ile ne yapıyor?" sorusuna cevap ararken; eleştirel çalışmalar içerisinde yer alan yaklaşımlar ise "Medya insanlara ne yapıyor? "sorusuna cevap aramaktadır (Tekinalp ve Uzun, 2009: 118).

Bu yaklaşıma göre izleyiciler birtakım ihtiyaçlarını gidermek için medya içeriklerini kullanırlar. Bu kullanmanın sonucunda izleyicinin ihtiyacı giderilmiş, yani ihtiyaç doyurulmuş; dolayısıyla da izleyiciler ihtiyaçları yönünde medya içeriklerini kullanarak doyuma ulaşmış olurlar (Yaylagül, 2014: 72).

\section{INTERNET HABERCİLIĞİ}

Küreselleşmeyle birlikte iletişim teknolojilerinin gelişmesi, internet haberciliğinde gelişimlerin yaşanmasını beraberinde getirmiştir. Artık yeni medya politikalarının gelişmesi haberlere erişilebilirliği kolaylaştırmış ve haberlerin sosyal paylaşım mecralarında da yayınlanabilmesini sağlamıştır. Sanallık üzerine kurulu olan internet haberciliği, zaman ve mekân kısıtlamasını ortadan kaldırmış ve yaşanan bu teknolojik gelişimlerle birlikte habercilik anlayışı da büyük bir değişim yaşamıştır. (Yurdigül ve Zinderen: 2012: 5).

Habercilerin yeni mecraya olan talepleri her geçen gün daha da artmıştır. Gazetecilerin internet haberciliğine bu denli rağbet göstermesinin nedenlerinden birisi haber kaynağına oturdukları yerden ulaşabilmeleri; bunun yanı sıra şehir, ülke veya kişi fark etmeksizin birçok bilgi ve kaynak ile rahatlıkla iletişim kurabilmeleri kaynaklıdır (Yücedoğan,2002: 3). Birçok bilgi ve kaynağa daha hızlı erișebilen habercilerin kaynak zenginliği de artmıştır. Bu nedenle hem hedef kitle açısından hem de haberci açısından internet haberciliği daha ilgi çekici hale gelmiştir (Taşkıran ve Kırık,2016: 219).

Yeni iletişim teknolojisinin gelişimiyle birlikte internet haberciliğinin ortaya çıkan yeniliklerinden bir diğeri ise habercilerin kaynak olarak sosyal medya paylaşımlarından yararlanmasıdır. Haberci, yayınladığ haberin kaynağı olarak sosyal medya (Facebook, twitter, instagram) uygulamalarındaki paylaşımları gösterebilmektedir.

Yaşanan gelişmeler ve değişimlerle birlikte haber anlayışında pratikte de farklılaşmalar yaşanmıştır. Bu farklılıklar, haberde asıl kaynak olarak kullanılan kişilerle doğrudan iletişim kurulması imkânını beraberinde getirmiştir. Ayrıca mesajı kuran kişinin üstünlüğü azalmış ve kişilerin şahsi görüntü, video veya yazılı açıklamalarına ulaş1labilir hale gelinmiştir (Yurdigül ve Zinderen: 2012: 5-6). Böylelikle internetle birlikte tek yönlü iletişim, yerini interaktif (etkileşimli) iletişime bırakmıştır.

\section{HABER KAYNAKLARI}


Haber kaynağı, en temel anlamda haber değeri olan bilginin alındığı kişi veya kurum olarak tanımlanabilir. Haber kaynakları habercilere; televizyon haberi, radyo haberi ve televizyon programina dönüşebilen temel bilgileri sağlamaktadır.

\subsection{Geleneksel Medya Haber Kaynaklar1}

\subsubsection{Birincil Kaynaklar}

- Temaslar

- Serbest Çalışanlar

- Rutin Çağrilar

- Bask1 gruplar1

- Mahkemeler

- Yerel Yönetimler

- Toplum işleri

- Basin Toplantiları 4.1.2. İkincil Kaynaklar

- Editöre Mektuplar

- Sinıflandirılmiș Haberler

- Basin Bültenleri

- Diğer Medya Kaynakları

- Haber Ajanslar1

- Haber Kuruluşları

- Merkezi Yönetimler

Kaynaklar gazetecilikte temel bir konudur. Bazı akademik araştırmalar, gazetecilerin kullandığı kaynakların sınırlı ve genellikle iktidar çıkışlı olduğunu göstermektedir. Ayrıca, anonim kaynaklar konusunun üzerinde düşülmesi gerekir; geleneksel gazetecilik görüşüne göre, anonimlik güvencesi verilen bir kaynak asla açıklanamaz. Bu ilke öyle önemlidir ki, bazı ülkeler, bilgi arayan kurum mahkeme dahi olsa gazetecilerin anonim kaynaklarını korumasina izin veren kanunlar kabul etmişlerdir. (http://elearning-events.dit.ie).

\section{2. İnternet Haberciliği Haber Kaynakları}

İnternet haberciliğinde geleneksel haber kaynaklarının yanı sıra, yeni medyanın getirisi olan 'sosyal medya' başlığı altında toplanmış haber kaynakları da kullanılmaktadır. Bu temel, sosyal medya platformlarından elde edilen bilgilerle haber yapılması esasına dayanir. $\mathrm{Bu}$ platformlara örnek olarak günümüzde en sık kullanılan; İnstagram, Twitter ve Facebook gösterilebilir. Muhabirler, bu platformlarda paylaşılan içerikleri, müdahalede bulunmadan haber yaparak platformu kaynak olarak kullanmaktadırlar. Sosyal medyadan elde edilen içeriklerin ve bilgilerin kaynak edinildiği haberlerin ağırlıklı olarak magazinsel ve eğlenceye yönelik haberler olduğu görülmektedir. 


\section{Amaç}

Dünya üzerinde her an yeni bir gelişme gösteren teknoloji, canlı yaşamının tüm alanlarını etkilemektedir. Gelişen medya teknolojileri ile birlikte hayatımızın her alanında önemli bir ivme kazanan sosyal medya, geleneksel yayın yapan mecralarda da kendini göstermeye başlamıştır. Bu çalışmada, sosyal medya kaynaklı haberlerin geleneksel yayın mecralarında kullanım oranını, kullanılış biçimlerini ve dağılımlarını ölçmek amaçlanmıştır.

\section{Kapsam ve Sinırlilıklar}

Çalışmada, öncelikle analiz edilecek mecralar tüm yayın kuruluşları arasından eşit bir şekilde seçilerek belirlenmiştir. Bu çalışmada geleneksel yayın mecralarından televizyon kanallarını temsilen FOX TV ve ATV, basılı gazeteleri temsilen Sözcü ve Yeni Şafak Gazetesi, internet haber sitelerini temsilen Habertürk, Mynet, Son Dakika ve Milliyet Haber siteleri incelenmisstir. Televizyon kanallarını temsil eden FOX TV ve ATV'nin ana haber bültenleri, internet haber sitelerini temsil eden Mynet, Milliyet, Son Dakika ve Habertürk sitelerinin 15 günlük süreçte tüm haber paylaşımları ve basılı gazetelerin söz konusu günlerdeki nüshaları analiz edilmiştir. Çalışmada belirtilen yayın mecralarının dışında farklı kaynaklara ise analizlerde yer verilmemiştir.

\section{Yöntem}

Çalışmada, sosyal medya kaynaklı haberlerin geleneksel yayın mecralarında kullanımını betimsel bir şekilde ortaya koymak için içerik analizi yöntemi kullanılmıştır. Teori kısmı olan birinci bölümde kapsamlı bir literatür taraması yapılmış, ikinci bölümde ise araştırmaya konu olan evrenin örneklemi, nicel araştırma yöntemlerinden içerik çözümlemesi yöntemi ile analiz edilmiştir.

Günümüzde s1k kullanılan bu mecralar 02.04.2018-16.04.2018 tarihleri arasında 15 günlük süre zarfında incelenerek 347 analiz formuna ulaşılmış ve bu formlar istatistik analiz programına aktarılmıştır. Haberlerin \% 5,2'si ATV'de, \%3,7'si FOX TV'de, \%5,8'i Yenişafak Gazetesi'nde, \%7,8'i Sözcü'de, \% 22,8'i Mynet'te, \% 4,3'ü Sondakika'da, \%23,6'sı Milliyet'te ve 28,6'sı Habertürk'te yayınlanmıştır.

Söz konusu haberler 14 kriterden oluşan "Haber Kodlama Formu" kullanılarak incelenmiştir. Kodlama formunda yer alan maddeler, haberin biçimsel ögelerini, haberlerin yapısal unsurlarını ve kaynaklarının yönünü ölçmeyi amaçlamıştır. Kodlama formu, ilgili literatürdeki bilimsel olarak yetkin kaynaklara dayanarak hazırlanmıştır. Bilimsel olarak geçerliliği olan istatistiksel bulgulara ulaşabilmek için, SPSS istatistik analiz programı kullanılmış, elde edilen nicel veriler nitel verilere dönüştürülerek yorumlanmıştır. Çalışmada istatistik analiz programı olan SPSS 25. 0 istatistik yazılımı kullanılarak 
elektronik ortamda işlenmiştir. SPSS programı içerisinde ise çapraz eşleştirme unsuru ve frekans analizi unsuru kullanılarak analizler tablo haline getirilmiştir.

\section{Bulgular ve Yorum}

$\mathrm{Bu}$ başlık altında sosyal medyadan yayılan olayların geleneksel haber mecralarında yer bulma oranlarının ve hangi mecrada ne tür haberlerin yer aldığının çapraz tablo ve frekans analizi bulgularına yer verilmiştir. Çalışmada öncelikli olarak sosyal medya kaynaklı olayların kitle iletişim araçlarında yer bulma sıklığı, frekans analizi sonuçlarıyla birlikte verilmisstir. Sirasıla televizyon kanalları, gazeteler ve internetteki haber sitelerinden elde edilen bulgulara yer verilmiştir.

Tablo 1: Televizyon Kanallarında Sosyal Medya Kaynaklı Olaylara Yer Verilme S1klığı

\begin{tabular}{|ll|l|l|l|l|}
\hline & & $\begin{array}{l}\text { Frequ- } \\
\text { ency }\end{array}$ & Percent & $\begin{array}{l}\text { Valid } \\
\text { cent }\end{array}$ & $\begin{array}{l}\text { Pumulative } \\
\text { Percent }\end{array}$ \\
\hline Valid & atv & 18 & 5,2 & 58,1 & 58,1 \\
& fox tv & 13 & 3,7 & 41,9 & 100,0 \\
& Total & 31 & 8,9 & 100,0 & \\
$\begin{array}{l}\text { Mis- } \\
\text { sing } \\
\text { Total }\end{array}$ & ,00 & 316 & $\begin{array}{l}\text { 91,1 } \\
100,0\end{array}$ & & \\
\hline
\end{tabular}

Tabo 2: Gazetelerde Sosyal Medya Kaynaklı Olaylara Yer Verilme S1klığı

\begin{tabular}{|l|l|l|l|l|}
\hline & $\begin{array}{l}\text { Frequ- } \\
\text { ency }\end{array}$ & Percent & $\begin{array}{l}\text { Valid Per- } \\
\text { cent }\end{array}$ & $\begin{array}{l}\text { Cumulative } \\
\text { Percent }\end{array}$ \\
\hline
\end{tabular}




\begin{tabular}{|c|c|c|c|c|c|}
\hline \multirow[t]{3}{*}{ Valid } & $\begin{array}{l}\text { Yeni Şa- } \\
\text { fak }\end{array}$ & 20 & 5,8 & 42,6 & 42,6 \\
\hline & Sözcü & 27 & 7,8 & 57,4 & 100,0 \\
\hline & Total & 47 & 13,5 & 100,0 & \\
\hline $\begin{array}{l}\text { Mis- } \\
\text { sing }\end{array}$ & ,00 & 300 & 86,5 & & \\
\hline Total & & 347 & 100,0 & & \\
\hline
\end{tabular}

Internet Sitelerinde Sosyal Medya Kaynaklı Olaylara Yer Verilme S1klığı

\begin{tabular}{|ll|l|l|ll|l|}
\hline & & $\begin{array}{l}\text { Frequ- } \\
\text { ency }\end{array}$ & Percent & $\begin{array}{l}\text { Valid } \\
\text { cent }\end{array}$ & Per- & $\begin{array}{l}\text { Cumulative } \\
\text { Percent }\end{array}$ \\
\hline Valid & Mynet & 79 & 22,8 & 29,4 & 29,4 \\
& $\begin{array}{l}\text { Sonda- } \\
\text { kika }\end{array}$ & 15 & 4,3 & 5,6 & 34,9 \\
& Milliyet & 82 & 23,6 & 30,5 & 65,4 \\
Habertürk & 93 & 26,8 & 34,6 & 100,0 \\
$\begin{array}{l}\text { Mis- } \\
\text { sing } \\
\text { Total }\end{array}$ &, 00 & 78 & 77,5 & 100,0 & \\
\hline
\end{tabular}

Tablolarda internet sitelerinin haber bulma konusunda sosyal medyadan daha çok beslendiği görülmektedir. Analiz edilen 347 haber içerisinde \%77,5’i internet sitelerinden elde edilmiştir. Yeni ve hızlı tüketilen sosyal medyanın kendisi gibi hızlı tüketilen internet sitelerinde geniş yer bulduğu söylenebilir. Buna karşıl1k, görsel destek ihtiyac1 duyan televizyonlarda sosyal medya kaynaklı olaylara \%8,9'luk bir 
oranla yer verildiği tespit edilmiştir. Sosyal medya kaynaklı olaylar, geleneksel haberciliğin temelini oluşturan basılı gazetelerde de $\% 13,5$ gibi düşük bir oranla yer bulabilmiştir. Bu duruma neden olarak gazete ve televizyonlarda haber oluşturma süresinin daha uzun sürmesi gösterilebilir.

Tablo 4: Sosyal Medya Kaynaklı Haberlerin Televizyonların Ana Haber Bültenlerinde Veriliş Sırası

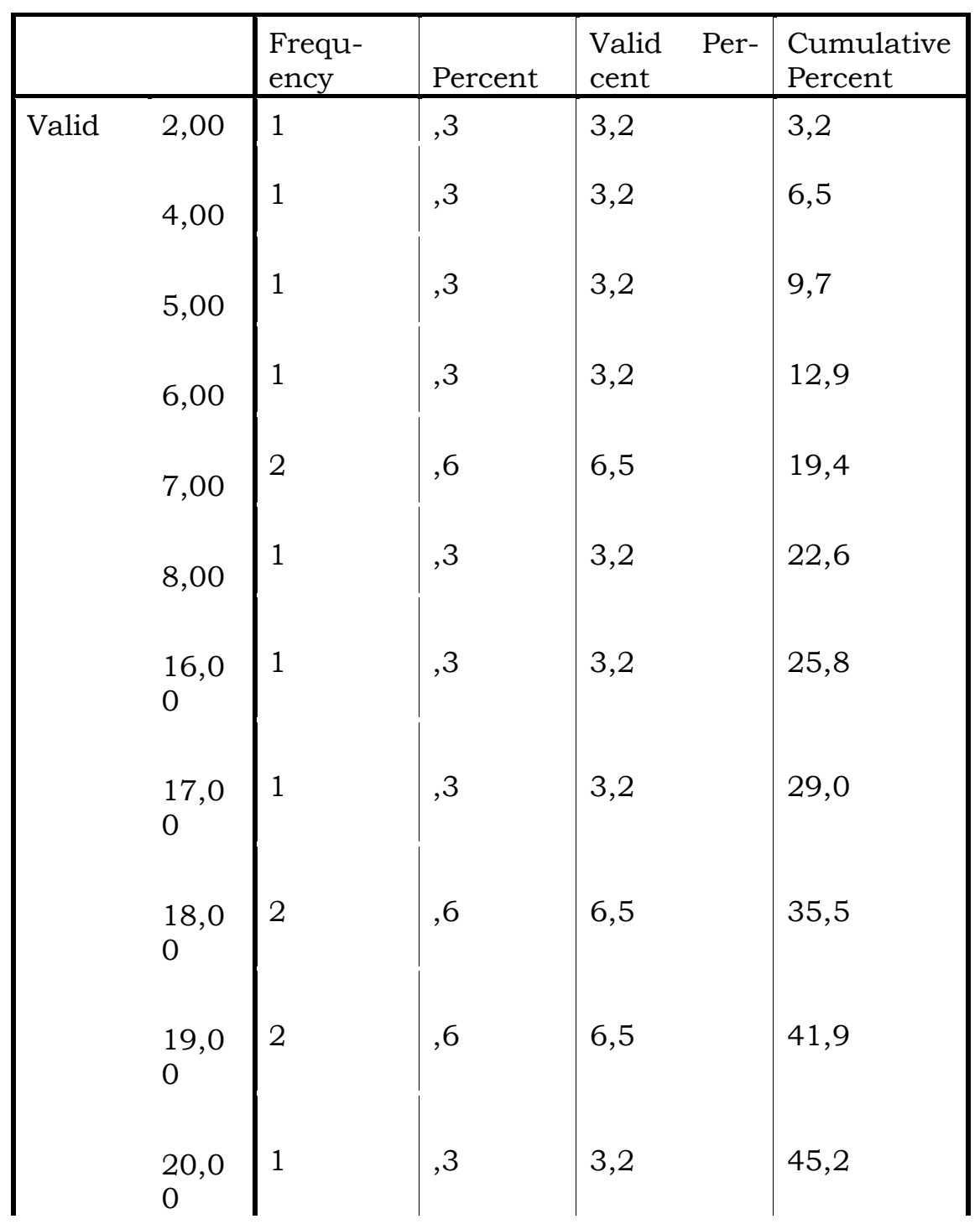


Sosyal Medya Kaynaklı Olaylarin Geleneksel Haber

\begin{tabular}{|c|c|c|c|c|c|}
\hline & $\begin{array}{l}21,0 \\
0\end{array}$ & 1 &, 3 & 3,2 & 48,4 \\
\hline & $\begin{array}{l}22,0 \\
0\end{array}$ & 1 & ,3 & 3,2 & 51,6 \\
\hline & $\begin{array}{l}23,0 \\
0\end{array}$ & 1 &, 3 & 3,2 & 54,8 \\
\hline & $\begin{array}{l}24,0 \\
0\end{array}$ & 2 & ,6 & 6,5 & 61,3 \\
\hline & $\begin{array}{l}25,0 \\
0\end{array}$ & 2 & ,6 & 6,5 & 67,7 \\
\hline & $\begin{array}{l}26,0 \\
0\end{array}$ & 1 &, 3 & 3,2 & 71,0 \\
\hline & $\begin{array}{l}27,0 \\
0\end{array}$ & 1 &, 3 & 3,2 & 74,2 \\
\hline & $\begin{array}{l}28,0 \\
0\end{array}$ & 2 & ,6 & 6,5 & 80,6 \\
\hline & $\begin{array}{l}29,0 \\
0\end{array}$ & 4 & 1,2 & 12,9 & 93,5 \\
\hline & $\begin{array}{l}30,0 \\
0\end{array}$ & 2 & ,6 & 6,5 & 100,0 \\
\hline & Total & 31 & 8,9 & 100,0 & \\
\hline $\begin{array}{l}\text { Mis- } \\
\text { sing }\end{array}$ & ,00 & 316 & 91,1 & & \\
\hline Total & & 347 & 100,0 & & \\
\hline
\end{tabular}


Televizyonların ana haber bültenleri için incelenen haber veriliş sıras1, değişkenlik göstermekle birlikte sosyal medyadan elde edilen haberlerin konusuna göre sıralandırıldığı tespit edilmiştir. Sosyal medya kaynaklı haberlere sıklıkla bültenin sonlarında yer verildiği tabloda görülmektedir. İncelenen 31 televizyon haberinden 4 tanesinin 29. sırada yer aldığı; buna karşılık 1 tane haberin bültenin 2. sırasında kendisine yer bulabildiği görülmüsstür.

Tablo 5: Haberlerin Konusu

\begin{tabular}{|l|l|l|l|l|}
\hline & $\begin{array}{l}\text { Frequ- } \\
\text { ency }\end{array}$ & Percent & $\begin{array}{l}\text { Valid Per- } \\
\text { cent }\end{array}$ & $\begin{array}{l}\text { Cumulative } \\
\text { Percent }\end{array}$ \\
\hline Valid Çok düşük & 175 & 50,4 & 50,4 & 50,4 \\
Düşük & 8 & 2,3 & 2,3 & 52,7 \\
Orta & 7 & 2,0 & 2,0 & 54,8 \\
Yüksek & 9 & 2,6 & 2,6 & 57,3 \\
Çok yüksek & 148 & 42,7 & 42,7 & 100,0 \\
Total & 347 & 100,0 & 100,0 & \\
\hline
\end{tabular}

Hızlı tüketilen internet sitelerinde kendisine ağırlıklı olarak yer bulan sosyal medya kaynakl haberlerde konu olarak magazin, spor, savaş ve siyaset gibi konuların yer aldığ belirlenmiștir. \%42,7 ile internet sitelerinde yer alan haberlerin konusunun magazin olduğu görülmüştür. Basılı gazetelerde sosyal medya üzerinden elde edilen haberlerin konusunun spor olduğu görülürken televizyonlarda ise eğlence ve savaş konuları ön plana çıkmaktadır.

Bu haberlerde kaynak olarak ünlülerin instagram hesaplarının ağırlıklı olarak kullanıldığı ortaya çıkmıştır. Ünlülerin sosyal medya paylaşımları özellikle internet sitelerinde magazin haberlerine önemli kaynak oluşturmaktadır.

\section{Tablo 6: Haberlerin Kaynakları}




\begin{tabular}{|ll|l|l|l|}
\hline \multirow{2}{*}{} & & \multicolumn{2}{|l|}{ instagram ünlüler } & Total \\
\cline { 3 - 5 } & & evet & hayır & \\
\hline $\begin{array}{l}\text { İnter- } \\
\text { net }\end{array}$ & Mynet & 26 & 53 & 79 \\
& $\begin{array}{l}\text { Sonda- } \\
\text { kika }\end{array}$ & 7 & 8 & 15 \\
& Milliyet & 34 & 48 & 82 \\
Total & $\begin{array}{l}\text { Haber- } \\
\text { türk }\end{array}$ & 44 & 49 & 93 \\
\hline
\end{tabular}

İnternet sitelerinin sosyal medyayı kaynak olarak kullanarak yayınladığı haberlerin \%41,3'ünün ünlülerin instagram paylaşımları olduğu ortaya çıkmıştır. İnternet siteleri içerisinde yapılan çapraz tablo analizinde ise geleneksel haber mecraları içerisinde de varlığını sürdüren kuruluşların bu tür paylaşımları ağırlıklı olarak kullandığı tespit edilmiştir. Hem basılı gazete olarak yayın hayatını sürdüren hem de internet üzerinden yayın yapan Habertürk'ün $\% 47,3$ ile ünlülerin sosyal medya paylaşımlarını en çok kullanan site olduğu, bunu yine aynı şekilde iki farklı alanda yayın hayatını sürdüren Milliyet'in ise \% 41,5 ile takip ettiği görülmüştür.

Haberlerde kullanılan anlatım tarzı ve üslupları incelendiğinde ise önceki analizlerle bağlantılı sonuçlar ortaya çıkmıştır. Magazin konusunun kullanıldığ haberlerde magazinsel bir üslup yer bulurken, spor haberlerinde bilgilendirici ve teknik üsluba yer verilmiştir.

Tablo 7: Haberin Anlatım Tarzı ve Üslubu

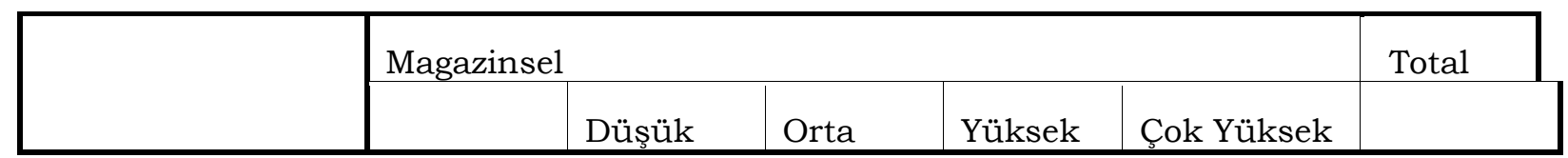




\begin{tabular}{|ll|l|l|l|l|l|l|}
\hline & $\begin{array}{l}\text { Çok dü- } \\
\text { sük }\end{array}$ & & & & & \\
\hline $\begin{array}{l}\text { İnter- } \\
\text { net }\end{array}$ & Mynet & 34 & 4 & 1 & 2 & 38 & 79 \\
& $\begin{array}{l}\text { Sonda- } \\
\text { kika }\end{array}$ & 4 & 0 & 0 & 2 & 9 & 15 \\
& Milliyet & 19 & 0 & 5 & 1 & 57 & 82 \\
& $\begin{array}{l}\text { Haber- } \\
\text { türk }\end{array}$ & 36 & 3 & 0 & 1 & 53 & 93 \\
Total & 93 & 7 & 6 & 6 & 157 & 269 \\
\hline
\end{tabular}

İnternet sitelerinde yayınlanan haberlerin \%58,4'ünün magazinsel bir üslupla yazıldığı görülmüştür. Televizyon haberlerinde ise eğlence içerikli görsellere yer verildiğinden kullanılan üslubun da mutluluk verici olduğu görülmüştür.

Tablo 8: Haberlerde Kullanılan Aktarma Yüklemleri

\begin{tabular}{|ll|l|l|l|}
\hline & & \multicolumn{2}{|l|}{ Olumlu } & Total \\
& & $\begin{array}{l}\text { Çok Dü- } \\
\text { sük }\end{array}$ & Çok Yüksek & \\
\hline TV Kanalı & ATV & 17 & 1 & 18 \\
& $\begin{array}{l}\text { FOX } \\
\text { TV }\end{array}$ & 9 & 4 & 13 \\
Total & 26 & 5 & 31 \\
\hline
\end{tabular}

Analizi yapılan haberlerde rastlanan diğer bir önemli bulgu ise kullanılan aktarma yüklemleridir. Sosyal medya kaynaklı televizyon haberlerinde aktarma yüklemlerine yer verilmediği görülmüștür. Sosyal medyada hızla yayılan videolara ağırlık verildiğinden bülten sonla- 
rında videoların metin yazılmadan gösterildiği tespit edilmiştir. İnternet siteleri ve gazetelerde ise benzer şekilde detaylı metin yazımına rastlanmamış, ağırlıklı olarak "paylaştı" yüklemine yer verildiği görülmüştür.

Tablo 9: Cümle Yapıları

\begin{tabular}{|ll|l|l|l|}
\hline & & \multicolumn{2}{|l|}{ etken } & Total \\
& & etken & edilgen & \\
\hline $\begin{array}{l}\text { Ga- } \\
\text { zete }\end{array}$ & $\begin{array}{l}\text { Yeni } \\
\text { fak }\end{array}$ & 18 & 2 & 20 \\
Total & Sözcü & 26 & 1 & 27 \\
\hline
\end{tabular}

Benzer şekilde haberlerde kullanılan cümle yapılarının da etken olduğu belirlenmiştir. Televizyon haberlerinde doğrudan aktarma yapıldığı için bu kategoriye alınmış ve \% 96'sının, gazetelerin \%93,6's1nin, internet sitelerinin \%89'unun etken cümle yapısında olduğu görülmüştür.

Tablo 10: Internet Sitelerinin Sosyal Medya Kaynağına Yönelik Tutumu

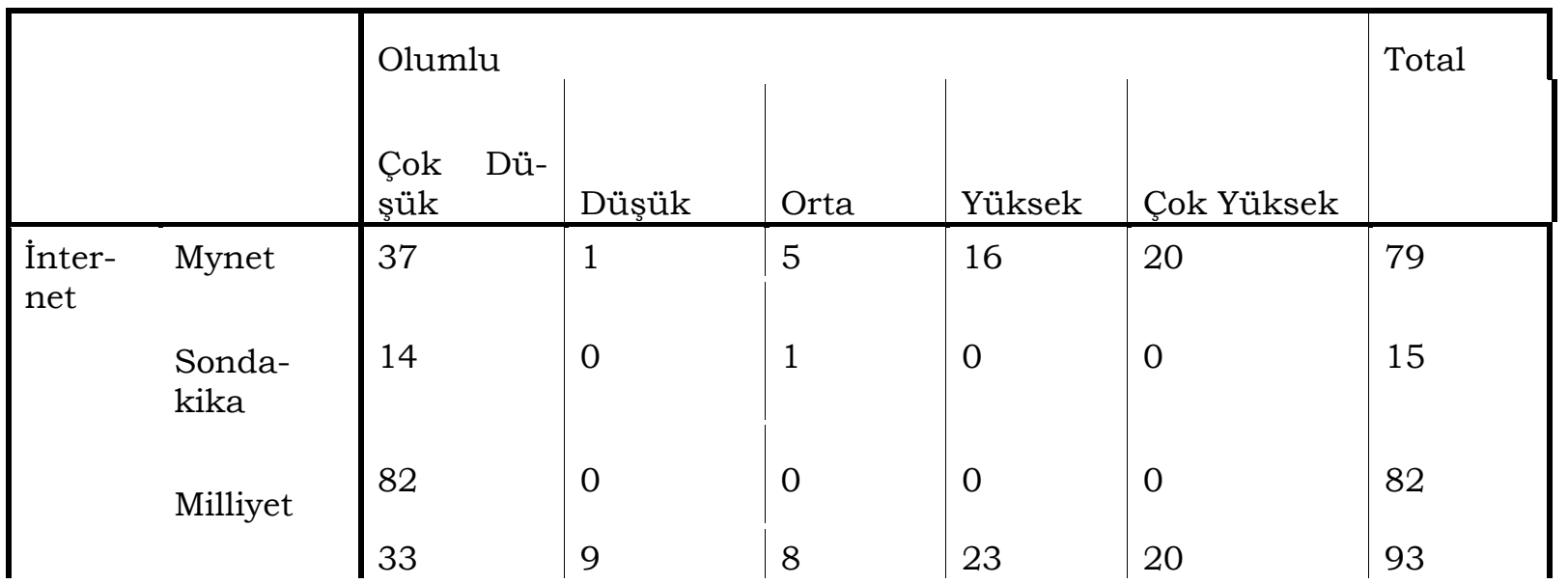




\begin{tabular}{|l|l|l|l|l|l|l|}
\hline Total & Habertürk & & & & & \\
\end{tabular}

İnternet sitelerinin sosyal medya kaynağına yönelik tutumları incelendiğinde $\% 37,5$ oranında yansız tutum sergilediği belirlenmiştir. Haberlerin \% 75,5'inin olumlu tutumda yazıldığı, \%4,5'inin de olumsuz bir tavırla yazıldığ görülmüştür.

Tablo 11: Televizyonların Sosyal Medya Kaynağına Yönelik Tutumu

\begin{tabular}{|c|c|c|c|c|}
\hline & \multicolumn{2}{|l|}{ Yansız(Nötr) } & \multirow[t]{2}{*}{ Tota } \\
\hline & & $\begin{array}{l}\text { Çok Dü- } \\
\text { şük }\end{array}$ & Çok Yüksek & \\
\hline TV Kanalı & ATV & 3 & 15 & 18 \\
\hline 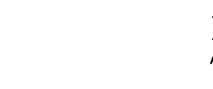 & $\begin{array}{l}\text { FOX } \\
\text { TV }\end{array}$ & 7 & 6 & 13 \\
\hline Total & & 10 & 21 & 31 \\
\hline
\end{tabular}

Televizyon haberlerinin \%25,8'inin sosyal medya kaynağına yönelik olumlu tutum sergilediği görülürken, \%6,5’inin olumsuz, \%67,7'sinin ise yansız tutumla yayınladığı ölçülmüştür.

Tablo 12: Gazetelerin Sosyal Medya Kaynağına Yönelik Tutumu

\begin{tabular}{|c|c|c|c|c|c|c|}
\hline & \multicolumn{4}{|l|}{ Olumsuz } & \multirow{2}{*}{ Total } \\
\hline & & $\begin{array}{l}\text { Çok Dü- } \\
\text { şük }\end{array}$ & Orta & Yüksek & Çok Yüksek & \\
\hline $\begin{array}{l}\text { Ga- } \\
\text { zete }\end{array}$ & $\begin{array}{l}\text { Yeni Şa- } \\
\text { fak }\end{array}$ & 16 & 0 & 2 & 2 & 20 \\
\hline & Sözcü & 21 & 3 & 2 & 1 & 27 \\
\hline Total & & 37 & 3 & 4 & 3 & 47 \\
\hline
\end{tabular}


Gazete haberlerinin ise \%12,8'inin olumlu yaklaşımla yazıldığı belirlenirken \%6,4'ünün olumsuz, \%31,9'unun ise yansız olduğu tespit edilmiştir.

Tablo 13: İnternet Sitelerinin Sosyal Medya Kaynağı Dışındaki Kaynağa Yönelik Tutumu

\begin{tabular}{|c|c|c|c|c|c|c|c|}
\hline & \multicolumn{5}{|l|}{ Olumsuz } & \multirow[t]{2}{*}{ Total } \\
\hline & & $\begin{array}{l}\text { Çok } \text { Dü- } \\
\text { şük }\end{array}$ & Düşük & Orta & Yüksek & Çok Yüksek & \\
\hline İnternet & Mynet & 51 & 4 & 3 & 10 & 11 & 79 \\
\hline & $\begin{array}{l}\text { Sonda- } \\
\text { kika }\end{array}$ & 15 & 0 & 0 & 0 & 0 & 15 \\
\hline & Milliyet & 79 & 0 & 1 & 1 & 1 & 82 \\
\hline & Habertürk & 76 & 8 & 1 & 5 & 3 & 93 \\
\hline Total & & 221 & 12 & 5 & 16 & 15 & 269 \\
\hline
\end{tabular}

Çalışmada sosyal medya kaynaklı haberlerin yayınlanma aşamasında elde eden kaynağa karşı tutumları da incelenmiştir. Çapraz tablo analiziyle yapilan incelemede internet sitelerinin sosyal medya kaynağ1 dişındaki kaynağa yönelik tutumunun \%29'unun olumlu, \% 11,5 'inin olumsuz ve \% 49,5'inin yansız olduğu ortaya konmuştur.

Tablo 14: Televizyon Kanallarının Sosyal Medya Kaynağı Dış1ndaki Kaynaklara Yönelik Tutumu

\begin{tabular}{|ll|l|l|l|}
\hline \multirow{2}{*}{} & \multicolumn{2}{|l|}{ Olumlu } & Total \\
\cline { 2 - 5 } & & \multicolumn{2}{l}{ Çok Dü- } & \\
șük & Çok Yüksek & \\
\hline TV Kanalı & ATV & 17 & 1 & 18 \\
& & 11 & 2 & 13
\end{tabular}




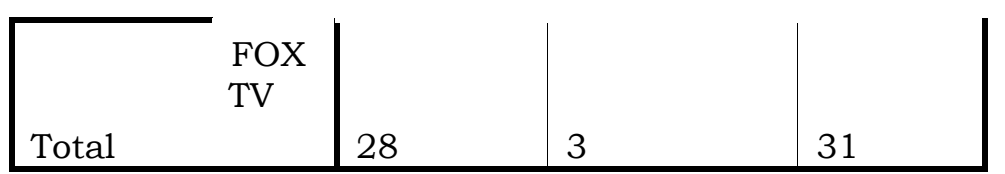

Televizyonların bu kaynaklara yönelik tutumu, \%9,7 oranında olumlu, \% 9,7 oranında olumsuz ve \%80,6 oranında yansiz olarak belirlenmiștir.

Tablo 15: Gazetelerin Sosyal Medya Kaynağı Dışındaki Kaynaklara Yönelik Tutumu

\begin{tabular}{|c|c|c|c|c|c|c|c|}
\hline & \multicolumn{5}{|c|}{ Yansız(Nötr) } & \multirow[t]{2}{*}{ Total } \\
\hline & & $\begin{array}{c}\text { Çok Dü- } \\
\text { şük }\end{array}$ & Düşük & Orta & Yüksek & Çok Yüksek & \\
\hline $\begin{array}{l}\text { Ga- } \\
\text { zete }\end{array}$ & $\begin{array}{l}\text { Yeni Şa- } \\
\text { fak }\end{array}$ & 6 & 4 & 0 & 2 & 8 & 20 \\
\hline & Sözcü & 5 & 5 & 2 & 7 & 8 & 27 \\
\hline Total & & 11 & 9 & 2 & 9 & 16 & 47 \\
\hline
\end{tabular}

Gazetelerdeki haberlerin ise \%55,5'inin yansız, \% 23,9'unun olumlu ve \%14,9'unun da olumsuz olduğu bulgularına ulaşılmıştır.

\section{SONUÇ}

Gelişen teknoloji ile birlikte günlük yaşantının ayrılmaz parçası haline gelen sosyal medya kullanımı, insanların haber alma ihtiyaçlarını da etkilemiştir. Sosyal medyada yayılan olayların geleneksel kitle iletişim araçlarında kendilerine ne kadar yer bulduğunun incelendiği bu çalışmanın araştırma tasarımı açısında genel olarak tanımlayıcı bir niteliğe sahip olduğu söylenebilir. Çalışmada incelenen internet sitelerinden basılı gazete olarak da yayın hayatını sürdüren Habertürk ve Milliyet'in yalnızca internet üzerinden yayın yapan Mynet ve Sondakika'ya göre sosyal medya kaynaklı haberlere daha fazla yer verdiği görülmüştür.

Aynı zamanda çalışmada ele alınan farklı siyasi görüşteki ticari televizyon kanalları olan FOX TV ve ATV'nin ana haber bültenlerinde 
ve aynı şekilde seçilen Sözcü ve Yeni Şafak gazetelerinin internet sitelerine göre sosyal medya kaynaklı haberlere daha az yer ayırdığı görülmüştür. Bu durumun haber oluşum süresinin uzunluğuna bağlı olduğu söylenebilir. İncelenen 347 haberin \% 28,6'sının Habertürk'te, \% 23,6'sının Milliyet'te, \% 22,8'inin Mynet'te, \%7,8'inin Sözcü Gazetesi'nde, \%5,8'inin Yeni Şafak Gazetesi'nde, \%5,2'sinin ATV'de ve $\% 3,7$ 'sinin de FOX TV'de yayınlandığı ortaya konmuştur.

İncelenen haberlerin büyük çoğunluğunun magazin, spor ve eğlence ağırlıklı konularda olduğu tespit edilmiştir. Bu sonuç, sosyal medyanın savaş, siyaset, suç gibi konulardan çok insanların eğlence ihtiyacına karşıllk verdiğini göstermiştir. Buna karşılık, yasal mercilerin ve güvenlik güçlerinin de sosyal medya kullanımını kamuoyunu bilgilendirmede kullanmaya başlaması düşünüldüğünde, haberlerin bir bölümünde savaş ve siyaset gibi gündemin önemli konularına da rastlandığını söylemek mümkündür. Bu konudaki haberlere özellikle televizyon kanallarının ana haber bültenlerinde geniş yer verildiği söylenebilir. Ana haber bültenlerinin sonlarında ise ağırlıkta tespit edilen eğlence içerikli hızlı tüketilen "fenomen videolar"ın herhangi metin yazımına ihtiyaç duyulmadan, doğrudan yayınlandığ görülmüştür. Gazetelerde ise daha kısa metne ihtiyaç duyan spor haberlerinin sosyal medyadan daha hızlı bir şekilde elde edildiği belirlenmiştir. Bu durum, geleneksel kitle iletissim araçları olan televizyon ve gazetelerin de sosyal medya ile bağlantılı olmaya çalıştı̆̆ını göstermektedir.

\section{KAYNAKÇA}

Erdoğan, İ. ve Alemdar, K., (2005), Öteki Kuram: Kitle İletişim Kuram ve Araştırmalarının Tarihsel ve Eleştirel Bir Değerlendirmesi, Erk Yayınları, Ankara.

Taşkıran ve Kırık (2016) Gazetelerin Sosyal Medyayı Haber Kaynağı Olarak Kullanımı: Medya Profesyonellerinin Bakış Açılarını Tespit Etmeye Yönelik Bir Araştırma. Intermedia Uluslararası eDergisi.

TDK (Türk Dil Kurumu), Haber, www.tdk.gov.tr., http:/ / www.tdk.gov.tr/index.php?option=com_gts\&kelime=HABER, Erişim Tarihi: 10, 06, 2018.

Tekinalp, Ş. ve Uzun, R. (2009), İletişim Araştırmaları ve Kuramları, Beta Yayınc1lık, İstanbul.

Tokgöz, O, (1981), Temel Gazetecilik, Ankara Üniversitesi Siyasal Bilgiler Fakültesi Yayınları, Ankara. 
Yaylagül, L., (2014), Kitle İletişim Kuramları, Dipnot Yayınları, Ankara.

Yurdigül ve Zinderen,İ. (2012). Yeni Medyada Haber Dili (Ayşe Paşalı Olayı Üzerinden Geleneksel Medya ve İnternet Haberciliği Karş1laştırmas1). Türk Online Tasarım, Sanat ve İletişim Dergisi.

Yücedoğan, G. (2002). İnternet Haberciliği. İstanbul Üniversitesi İletişim Fakültesi Dergisi.

\section{INTERNET KAYNAKLARI}

Pelin, Avluoğlu., (2017), Geleneksel Medya ve Yeni Medya, dijitalmedyauzmanliği.com, http://dijitalmedyauzmanligi.com/yenimedya/geleneksel-medya-ve-yeni/, ET:10.06.2018).

http://elearning-events.dit.ie/UNICEF-TK/unit2/2_4_6.htm, (Erişim Tarihi: 08.06.2018, 14:50) 